\author{
Alicja Jurgiel-Aleksander \\ Uniwersytet Gdański \\ pedamj@ug.edu.pl
}

\title{
Dorosły w świadomości przedszkolaka. Esej prawie naukowy
}

\section{Summary \\ An adult according to a pre-schooler. An almost scientific essay}

The aim of the following text is to present various manners of thinking about adults by five-year olds. On the basis of group interviews the author tries to recognize how children perceive adults. Despite the fact that this research ought to be treated only as a case study, the outcome shown in the essay depicts the children's world. What is more it also shows how we, the adults, rear children. It was demonstrated that children view us as individuals physically resembling themselves, extremely busy at work, privileged when it comes to doing things that children cannot, great role models and good guardians. They do realize that in the adult world there are people who can do harm to them. To us it may seem that all these revelations are nothing new, but the results can show that we fail to treat children as partners.

Słowa kluczowe: stadium przypadku, świat dzieci, uczenie się od dzieci

Keywords: case study, the world of children, learning from children

\section{Wprowadzenie}

Niniejszy tekst pośrednio służy prezentacji wypowiedzi przedszkolaków na temat dorosłych i dorosłości po to, by w rezultacie spróbować opisać, w jaki sposób dzieci postrzegają nas (dorosłych), którzy im urządzają świat. W sensie poznawczym rozmowa z dziećmi o dorosłych stała się pretekstem do rozważenia znaczenia dorosłych w ich codzienności. W konsekwencji chodzi jednak o to, by zobaczyć, jak nas widzą dzieci i czego możemy się od nich nauczyć w kwestii ich wychowywania. Prezentowany materiał należy traktować jako jakościowe studium przypadku zorientowane na opis zjawiska, jakim jest znaczenie dorosłych w świecie dziecka (Stake 2009). Natomiast krytyczny ${ }^{1}$ potencjał tego studium

\footnotetext{
$1 \mathrm{~W}$ polskim piśmiennictwie sformułowanie badania krytyczne utożsamiane jest z pedagogiką radykalną, mistrzostwem podejrzeń w ujęciu klasyków takich jak: Marks, Nietzsche, Freud. Natomiast ja używam tego sformułowania w sposób uproszczony, jako badania nad procesem wychowania rozumianym jako konstrukt społeczny i kulturowy co oznacza, konstruowanym a nie jedynie wdrażanym. $Z$ tego względu interesują mnie koncepcje znaczeń dotyczące zjawisk w edukacji i wychowaniu, które są produkowane przez to, co ma miejsce w kulturze i życiu społecznym. W taki sposób o byciu krytycznym piszą W. Carr, S. Kemmis (1991), Becoming Critical. Education, Knowledge and Action Research, London and Philadelphia.
} 
odnosi się tu do sposobu ujmowania tej sprawy jako ważnej dla uczenia się dorosłych, dokładnie uczenia się bycia w roli tego, który ten świat dziecku tworzy.

\section{Kilka uwag o metodzie w realizowanym projekcie badawczym}

Problem widzenia świata przez dzieci zawsze stanowił przedmiot zainteresowania pedagogów głównie ze względu na pytanie o możliwe instrumentarium do rozpoznawania procesów poznawczych, które zachodzą w ich świadomości, a stanowią o możliwościach rozwoju dziecka i jego kompetencji. W niniejszym projekcie mam znacznie skromniejszy cel - ponieważ próbuję rozpoznać, jakimi widzą dorosłych dzieci i to głównie ze względu na to, by odsłonić, kim są dorośli w życiu dziecka, jaki świat współtworzą z dziećmi. W przełożeniu na język praktyki badawczej chodziło o to, by za pomocą pytań w wywiadzie typu: Kim jest dorosty? Po co sa dorośli? Czy sa nam potrzebni? Kiedy jest się dorosłym i jak to rozpoznać? wywołać dziecięcą opowieść, a następnie dokonać jej analizy ukierunkowanej na odpowiedź co to może znaczyć, co mówią dzieci w tym konkretnym kontekście kulturowym i społecznym.

Dla pokazania tej kwestii wybrałam metodę fenomenograficzną ${ }^{2}$, która jako sposób postępowania badawczego prowadzi do wytwarzania koncepcji znaczeń nadawanych rzeczywistości na podstawie tego, czego doświadczamy. W tym sensie jej rezultatem są opisy zjawiska w języku realnego odwzorowywania tego, jaki świat jawi nam się w bezpośrednim doświadczeniu, ale ów opis traktuje jako sposób rozumienia (a nie psychologiczny proces postrzegania). Metoda ta wskazuje na to, że to, w jaki sposób o czymś mówimy świadczy o tym, jak to rozumiemy, a to, jak rozumiemy jest pochodną tego, czego doświadczamy. W dosłownym tłumaczeniu fenomenografia oznacza opis rzeczy, zjawisk, które ujawniają nam się w bezpośrednim doświadczeniu. Sam jej twórca Ferenc Marton, w swoich publikacjach pisze, że fenomenografia to empiryczne studium ograniczonej liczby jakościowo różnych sposobów rozumienia, postrzegania, konceptualizowania, doświadczania zjawisk otaczającego świata (Marton, Booth 1997). Rezultatem poznawczym fenomenografii jest „rysowanie” przez badaczy mapy ujawniającej różne sposoby doświadczania zjawisk przez badanych. Ich odczytanie i konceptualizacja ma swoje konsekwencje praktyczne. Zarówno samemu twórcy metody, jak i jego współpracowni-

\footnotetext{
2 Na łamach „Problemów Wczesnej Edukacji” badania zgodnie z założeniami tej metody były już kilkukrotnie prezentowane. Szczegółową prezentację tego podejścia proponuję w publikacji: A. Jurgiel (2009b), O możliwościach poznawczych fenomenografii. „Pedagogika Kultury”, tom 5; A. Jurgiel (2009a), Doświadczanie szkoły przez uczniów. Rekonstrukcja fenomenograficzne. „Problemy Wczesnej Edukacji”, nr 2. Inne, które przedstawiają tę procedurę w polskim piśmiennictwie naukowym to między innymi: L. Kopciewicz (2005), Kobiecość, męskość i przemoc symboliczna. Polsko-francusko studium porównawcze. Kraków; L. Kopciewicz (2007), Rodzaj i edukacja. Studium fenomenograficzne z zastosowaniem teorii społecznej Pierre'a Bourdieu. Wrocław; Kopciewicz L. (2014), ,Nieracjonalna i nietwórcza, bo dziewczynka", czyli dezintegracja genderowa jako efekt stereotypizacyjnej pracy szkoły. W: D. Klus-Stańska (red.), (Anty)edukacja wczesnoszkolna. Kraków; A. Męczkowska (2003), Fenomenografia jako podejście badawcze w obszarze studiów edukacyjnych. „Kwartalnik Pedagogiczny”, nr 3.
} 
kom zależało bowiem na ulepszeniu procesu kształcenia w uniwersytecie, dlatego pytania poznawcze, które wtedy sformułowali miały następującą postać: Co to znaczy, że jedni ludzie są lepsi a drudzy gorsi w uczeniu się? Dlaczego jedni radzą sobie lepiej od innych w uczeniu się? Odczytanie rozmaitych sposobów rozumienia (doświadczania) uczenia się przez studentów stanowiło cel tamtego i późniejszych badań fenomenograficznych. Marton (1986) zwykł mówić, że na ogół w pracy edukacyjnej opieramy się na założeniu, że uczeń myśli i robi coś źle, a w związku z tym my to „coś” poprawiamy. Tymczasem fakt, że uczeń robi coś inaczej niż byśmy tego oczekiwali wynika z faktu, że w inny sposób niż my (dorośli, nauczyciele) rozumie jakieś zjawisko (Jurgiel 2009b).

Odnosząc powyższe założenie do dyskusji z dziećmi na temat kim są dorośli, oznaczało by to, że ich opowieści zyskują status nie tylko realnego opisu rzeczywistości, w której dorośli są obecni, ale co ważniejsze, przez różne rodzaje swej obecności w świecie dzieci koncepcja bycia dorosłym wskazuje, jak ten świat jest przez dzieci rozumiany.

W sensie technicznym sposób postępowania w przedstawianym projekcie obejmował kilka etapów:

a) gromadzenie danych za pomocą wywiadu grupowego przeprowadzonego wśród pięciolatków w jednym z trójmiejskich przedszkoli wywołanym pytaniem³: Kim są dorośli?

b) przygotowanie transkrypcji nagranych wywiadów,

c) analizę tekstu wywiadu typową dla procedury fenomenograficznej polegającą na:

- kondensowaniu fragmentów tekstu wypowiedzi wokół jednej kwestii, różnej od pozostałych,

- wyłonieniu kontekstu decydującego o powstaniu jednorodnego pola tematycznego,

- pokazaniu różnic w wypowiedziach (kontekstach) wobec innych pól tematycznych,

- wyłonieniu kategorii opisu, rozumianej jako jednorodny pod względem nadawanego znaczenia obraz fenomenu. Należy zaznaczyć, że fenomenografia jako metoda badań - zakłada różnorodność rozumienia zjawiska, tym samym dąży do wyłonienia wielu kategorii opisu świadczących o jego rozumieniu (zob. Jurgiel-Aleksander 2013).

W niniejszym projekcie traktowanym jako studium przypadku możliwości opisu, jakie zostaną tu przedstawione nie wyczerpują przestrzeni wynikowej w sensie fenomenograficznym, a jedynie są sygnałem ważnej (wyjątkowej) kwestii. Okazuje się bowiem, że obraz dorosłego wyrażony w języku pięciolatka stał się pośrednio kluczem do rozpoznania doświadczenia wychowania jako procesu społeczno-kulturowego, którego twórcami są jego rodzice i najbliżsi.

Wywiady według mojej koncepcji przeprowadziła studentka pedagogiki UG. 


\section{Dorosły, czyli kto? Znaczenie dorosłych w świecie dziecka}

Na podstawie zastosowanej procedury wyłoniłam sześć rodzajów kategorii opisu dorosłego, świadczących o znaczeniu dorosłego w życiu społecznym i kulturowym. Interesujące jest to, że w każdym z tych pomysłów możemy odnaleźć język współczesnej andragogiki, oczywiście w dziecięcym wydaniu.

Pierwszą z kategorii opisu jest rozumienie dorosłego jako istoty fizycznie podobnej do dziecka. W tym rozpoznaniu dorosłości dominują wskazania na osoby z najbliższego otoczenia jak mama, tata, ciocia, dziadek, babcia głównie ze względu na cechy fizyczne, jak noszenie wąsów, butów na obcasie, ale także ze względu na cechy organicznego wzrostu o czym świadczą pokaźne rozmiary. Dorosły jest zawsze duży, a dzieci małe - jak mówią przedszkolaki. Oto wypowiedzi w tej kwestii: Jak wygladaja dorośli?

- Mają oczy nos $i$ wąsy.

- Maja duża buzię i okulary.

- Mają duże brzuchy.

- Nosza czarne buty na obcasie jak moja mama.

Zaobserwowanie cech wyglądu, sposobu ubierania się innego niż dzieci - jak w powyższych wypowiedziach - nie oznacza niezauważania podobieństw:

- Są tacy jak my, tylko trochę duzi!

Wytłumaczenie, dlaczego muszą być więksi pochodzi ze społecznego świata: bo musza nosić dzieci na rękach albo zakupy ze sklepu.

Drugą z kategorii opisu jest widzenie dorosłego jako osoby zapracowanej. Domeną tego fragmentu wypowiedzi jest wskazywanie na aktywności zarezerwowane dla dorosłych, bo wymagające zwyczajnie siły, ale też odpowiedzialności za kogoś innego. Dorośli w tym wydaniu:

- Pilnuja dzieci i pieska.

- Chodza do pracy i zarabiaja pieniązki.

- Moga też gotować, ale ja z mama tez gotuję!

- Myja okna, moga tez parapety.

- Robia zakupy i kupuja ryby.

Są też konsekwencje związane z podejmowaniem różnych obowiązków, a mianowicie to, że:

trzeba pracować i nie ma się czasu dla dzieci.

Trzecią kategorię opisu konstruują wypowiedzi o dorosłych jako tych, którzy mają przywileje. Przywileje to coś, co jest niedostępne dziecku, ale będzie w przyszłości. Do 
nich zaliczają: oglądanie filmów, jazdę samochodem w roli kierowcy, ale także korzystanie z używek, jak w tych oto wypowiedziach:

- Dorośli mogą jeździć samochodem i być za kierownicą.

- Mogą palić papierosy albo pić piwo, jak mój wujek.

- Mogą oglądać filmy dla dorosłych, a my nie!

Rodzajem przywileju jest także kształtowanie estetyki charakterystycznej dla ubioru i wyglądu dorosłych:

- Dorośli moga malować włosy, jak moja mama.

- Dorośli nosza kolczyki jak mój tata.

Kolejna kategorię opisu budują przekonania o dorosłym jako osobie zachowującej się poprawnie i godnej naśladowania. Ten rodzaj poprawnych zachowań odnosi się zarówno do tych społecznie akceptowalnych, związanych z funkcjonowaniem w życiu społecznym, kiedy mówią, że:

- Dorośli nie moga scypać ani marudzić!

- Ani plakać!

- Ani popychać!

- Ani brzydkiej miny robić!

Ale także do wyboru przyszłej roli zawodowej wtedy, gdy demonstrują, że będą naśladować kariery swoich rodziców:

- Ja tez będę pracowat jak tata! W Ergo Hestia!

- Ja będę strażakiem, jak mój!

W świecie dziecka pojawiają się również tacy dorośli, którzy stanowią zagrożenie, bo nie tylko nie zachowują się poprawnie, ale mogą wyrządzić krzywdę. Świadomość, że tacy też istnieją jest budowana przez rodziców w oparciu o system nakazów:

- Dorośli sa dobrzy i źli też. Złodzieja nie można wpuszczać do domu, bo by się mama zezłościła!

- Jak mama idzie do sklepu - a ja zostaje czasem sama - to nigdy nie otwieram drzwi!

Dorośli jako opiekunowie dziecka, to kolejna kategoria opisu. Została utworzona w języku budowania zaufania i zapewniania bezpieczeństwa dzieciom. Oto wypowiedzi w tej sprawie:

- Jak na przykład Szymek się zrani i nie ma mamy albo taty, to nie może sobie sam założyć plasterka. Musi być mama labo tata. 
- Muszą dzieciom śpiewać kotysanki.

- Musza przytulać, jakby dzieci miały zły sen.

- Musza szykować kapiel, czytać książke na dobranoc i wtączać bajkę na dobranoc.

- Daja dzieciom picie.

- Jakby ich nie byto, to dzieci mogłyby się zgubić, jak idq na spacer.

- Dorośli sa po to, żeby pomagać dzieciom wciagać sanki na górkę.

\section{Czego my dorośli uczymy się od dzieci?}

Wszystkie przedstawione dotychczas kategorie opisu dorosłego pokazują jak dzieci identyfikują swój świat, którego dorośli są nieodłączną częścią. Ich język tworzenia wizerunku dorosłego może świadczyć o tym, że mechanizm socjalizacji działa. W swoim krótkim opowiadaniu o tym kim są dorośli w języku społecznej przydatności (,pracują”, „robią zakupy”, „pomagają wciągać sanki dzieciom”) oraz języku obowiązków wobec innych, w domyśle - młodszych (,muszą pracować”, „muszą zarabiać pieniążki”, „muszą włączać bajkę na dobranoc i dawać dzieciom picie”) zawarta jest konieczność dopasowywania się do świata, który po prostu jest. Dzieci rozumieją znaczenie norm społecznych, zdają sobie sprawę z ich istnienia, widzą dorosłych jako ich twórców. W oczach badanych to dorośli są idealni, racjonalni, zachowują się zgodnie z oczekiwaniami społecznymi i normami. I to oni pomagają dzieciom w codziennym funkcjonowaniu, opiekując się nimi i realizując niezbędną potrzebę bezpieczeństwa. $Z$ punktu widzenia rozwoju społecznego i moralnego można by powiedzieć, że przedszkolaki w tym studium przypadku reprezentują charakterystyczny dla pięciolatków typ zachowania oraz że w procesie ich wychowania obecni są znaczący inni (rodzice, dziadkowie), których rola jest niezwykle istotna (Bee 2004). Wydaje się, że nie ma w tym odkryciu, dla nas badaczy, nic poznawczo zaskakującego. Gdybyśmy jednak odwrócili tę sytuację i zapytali, co robią w tym procesie wychowania dorośli, to można zauważyć, że - z punktu widzenia opisywanej tu koncepcji bycia dorosłym w ujęciu przedszkolaka - nie wychodzą oni poza rolę opiekuńczą, ponieważ „doglądają”, pomagają, usuwają przeszkody, mówią, co dobre, a co złe i jak należy się zachować. Może jest więc tak, że dorośli kładą nacisk na realizację funkcji opiekuńczych na tym akurat etapie wychowania swoich dzieci. A może jest też tak, że funkcjonalizm naszej kultury nie pozwala sobie nawet wyobrazić, że wychowanie to nie tylko świat sam w sobie, ale społeczny rodzaj doświadczeń w równym stopniu współtworzony przez dzieci i dorosłych. Ten rodzaj małego eksperymentu myślowego jest raczej zaproszeniem do rozmowy na ten temat. Temat, który mnie - badaczkę uczenia się dorosłych - zainspirował do przyglądania się temu, co o nas dorosłych mówią i myślą dzieci. Należy dodać, że z punktu widzenia zastosowanej tu metody, przedstawiona przestrzeń wynikowa w żadnej mierze nie upoważnia do wysuwania tezy o braku traktowania wychowania przez dorosłych jako społecznego doświadczenia. Jest raczej powodem do zastanowienia się nad tym, że w próbie ścierania się rozmaitych doświadczeń, wysiłku zmiany świata na lepszy, kiedy uwiera on nas swoją jakością musimy mieć, jako dorośli, młodszych sojuszników. 
Ich rozumienie świata, sposób jego doświadczania mówi coś ważnego o nas. Pozostaje tylko pytanie - na ile zechcemy to „coś” usłyszeć. Może więc rację miała M. Mead (2000) mówiąc, że świat, w którym dorośli uczą się od dzieci ma szansę stać się bardziej demokratyczny, a może przede wszystkim bardziej zrozumiały dla nas dorosłych?

\section{Literatura}

Bee H. (2004), Psychologia rozwoju człowieka. Poznań, Zysk i S-ka.

Carr W., Kemmis S. (1991), Becoming Critical. Education, Knowledge and Action Research. London and Philadelphia, Falmer Press.

Jurgiel A. (2009a), Doświadczanie szkoły przez uczniów. Rekonstrukcja fenomenograficzne. „Problemy Wczesnej Edukacji”, nr 2.

Jurgiel A. (2009b), O możliwościach poznawczych fenomenografii. „Pedagogika Kultury”, tom 5.

Jurgiel-Aleksander A. (2013), Doświadczenie edukacyjne w perspektywie andragogicznej. Studium biograficzno-fenomenograficzne. Gdańsk, Wydawnictwo Uniwersytetu Gdańskiego.

Kopciewicz L. (2007), Rodzaj i edukacja. Studium fenomenograficzne z zastosowaniem teorii społecznej Pierre’a Bourdieu. Wrocław, Wydawnictwo Dolnośląskiej Szkoły Wyższej.

Kopciewicz L. (2005), Kobiecość, męskość i przemoc symboliczna. Polsko-francuskie studium porównawcze. Kraków, „Impuls”.

Kopciewicz L. (2014), „Nieracjonalna i nietwórcza, bo dziewczynka”, czyli dezintegracja genderowa jako efekt stereotypizacyjnej pracy szkoły. W: D. Klus-Stańska (red.), (Anty) edukacja wczesnoszkolna, Kraków, Oficyna Wydawnicza Impuls.

Marton F., Booth S. (1997), Learning and awareness. Mahwah, N.J. Erlbaum Associates.

Marton F. (1986), Phenomenography: A Research Approach to Investigating Different Understandings of Reality. „Journal of Thought”, vol. 21, no 3.

Mead M. (2000), Kultura i tożsamość: studium dystansu międzypokoleniowego. Warszawa, Wydawnictwo Naukowe PWN.

Męczkowska A. (2003), Fenomenografia jako podejście badawcze w obszarze studiów edukacyjnych. „Kwartalnik Pedagogiczny”, nr 3.

Stake R.E. (2009), Jakościowe studium przypadku. W: N. Denzin, Y. Lincoln (red.), Metody badań jakościowych. Tom 1. Warszawa, Wydawnictwo Naukowe PWN. 